\title{
PENGARUH PENAMBAHAN Gracilaria Sp. TERHADAP MUTU SOSIS IKAN BANDENG (Chanos chanos)
}

\author{
THE EFFECTS OF ADDITION OF Gracilaria sp. ON THE QUALITY OF MILKFISH \\ SAUSAGE (Chanos chanos)
}

\author{
Aef Permadi, Devi Wulansari*, Anasri Tanjung, Aripudin \\ Politeknik Kelautan dan Perikanan Karawang, Jalan Lingkar Tanjungpura, Karangpawitan, Kecamatan \\ Karawang Barat, Kabupaten Karawang, Jawa Barat 41315
}

Teregistrasi I tanggal: 10 April 2020; Diterima setelah perbaikan tanggal: 6 Mei 2020; Disetujui terbit tanggal: 23 Mei 2020

\begin{abstract}
ABSTRAK
Sosis ikan mengandung protein tinggi yang dapat bermanfaat bagi pertumbuhan anak. Sosis ikan dapat dikombinasikan dengan sumber gizi lain untuk meningkatkan nilai gizinya. Penambahan Gracilaria sp. dalam pembuatan sosis ikan bandeng dapat meningkatkan nilai gizi dan kandungan serat pangannya (dietary fiber). Penelitian ini bertujuan untuk mengetahui perbandingan bubur Gracilaria sp. dan daging ikan bandeng yang disukai panelis, dan pengaruh penambahan konsentrasi bubur Gracilaria sp. terhadap kadar proksimat dan zat besi pada sosis ikan bandeng. Objek penelitian dibagi menjadi 2 (dua) kelompok percobaan yaitu: A0, kelompok kontrol (sosis ikan bandeng tanpa penambahan bubur Gracilaria sp.) dan A1, kelompok sosis ikan bandeng dengan penambahan bubur Gracilaria sp. Penambahan bubur Gracilaria sp. sebanyak 1: 8 (70 g : $580 \mathrm{~g}$ ) dari berat lumatan daging ikan menghasilkan produk yang disukai oleh panelis dengan penambahan bubur Gracilaria sp. dapat meningkatkan nilai tekstur dan gel forming ability, serta dapat meningkatkan kadar serat pada sosis, namun mempengaruhi penurunan kadar protein dan lemak.
\end{abstract}

Kata kunci: Gracilaria sp., mutu, sosis ikan bandeng

\begin{abstract}
Fish sausages contain high protein which can be beneficial for children's growth. Fish sausages can be combined with other nutrition sources to increase nutritional value. The addition of Gracilaria sp. in the production of milkfish sausage can increase the nutritional value and dietary fibre content. This study aims to determine the proportion of Gracilaria sp. pulp and milkfish that is preferred by the panellists and to assess the effect of adding Gracilaria sp. pulp concentration on the proximate and Fe content in milkfish sausage. This study applied 2 (two) experimental groups, namely A0, control group (milkfish sausages without the addition of Gracilaria sp. pulp) and Al: a group of milkfish sausage with the addition of Gracilaria sp. pulp. The addition of Gracilaria sp. pulp as much as 1:8 (70 g: $580 \mathrm{~g})$ of the weight of fish meat produced a product which is preferred by the panellists; and the addition of Gracilaria sp. pulp could increase the value of texture and gel forming ability, and could increase the fibre content in sausages, yet decreased the level of protein and fat content.
\end{abstract}

Keywords: Gracilaria sp., quality, milkfish sausage

\footnotetext{
Korespondensi penulis:

*Email: nadhifagha@gmail.com

DOI: http://dx.doi.org/10.15578/plgc.v1i2.8884
} 


\section{PENDAHULUAN}

Ikan bandeng (Chanos chanos) merupakan komoditas hasil perikanan budidaya yang utama di Karawang. Berdasarkan data Badan Pusat Statistik Kabupaten Karawang (2015), produksi ikan bandeng mencapai 17.618,28 ton. Selama ini masyarakat Karawang mengolah ikan bandeng menjadi olahan bandeng presto, bandeng gepuk, nugget, siomay, kerupuk, sarden, dan olahan fish jelly seperti bakso dan sosis. Selain ikan bandeng rumput laut jenis Gracilaria sp. juga cukup melimpah di perairan Kabupaten Karawang, terutama di wilayah pesisir di wilayah Tirtajaya. Selama ini, masyarakat di daerah tersebut membudidayakan rumput laut secara komersial untuk dijual dalam bentuk kering ke PT Agarindo (Waluyo et al., 2019). Gracilaria sp. mengandung BASS (Bioactive Seaweed Substances) yang bermanfaat bagi kesehatan. Selain kaya akan serat pangan, Gracilaria sp. juga tinggi akan kandungan mineral terutama kalium dan zat besi. Zat besi berfungsi untuk mencegah anemia yang diakibatkan defisiensi zat besi. Jika anak-anak mengalami defisiensi zat besi, maka resiko stunting (kekerdilan) akan meningkat (Burry et al., 2011).

Keadaan kesehatan dan gizi kelompok usia 10-24 tahun di Indonesia masih memprihatinkan. Data Riskesdas 2013 menunjukkan bahwa prevalensi anemia pada wanita usia subur yang berusia 15 tahun ke atas sebesar 22,7\%, sedangkan pada ibu hamil sebesar $37,1 \%$. Remaja putri yang menderita anemia ketika menjadi ibu hamil berisiko melahirkan Berat Bayi Lahir Rendah (BBLR) dan stunting (kekerdilan). Anemia gizi besi menjadi salah satu tipe anemia terbesar, diantaranya disebabkan oleh asupan makanan sumber zat besi yang kurang (Direktorat Gizi Masyarakat, 2016).

Remaja putri pada masa pubertas sangat berisiko mengalami anemia gizi besi. Hal ini disebabkan banyaknya zat besi yang hilang selama menstruasi. Selain itu, hal ini dapat diperburuk oleh kurangnya asupan zat besi, dimana zat besi pada remaja putri sangat dibutuhkan tubuh untuk percepatan pertumbuhan dan perkembangan. Pada masa hamil, kebutuhan zat besi meningkat tiga kali lipat karena terjadi peningkatan jumlah sel darah merah ibu untuk memenuhi kebutuhan pembentukan plasenta dan pertumbuhan janin (Direktorat Gizi Masyarakat, 2016).

Gracilaria sp. secara umum diekstrak menjadi agar sebelum dimanfaatkan menjadi berbagai produk olahan, salah satunya ditambahkan sebagai bahan penstabil dan pengemulsi pada pembuatan sosis ikan. Daging ikan memiliki kekuatan gel yang cukup rendah, karena protein myofibril yang mudah larut dalam larutan garam saat proses pembuatan. Penambahan agar meningkatkan daya ikat air sehingga tekstur sosis ikan menjadi lebih kompak (Kharisma et al., 2016). Sosis ikan mengandung protein tinggi yang dapat bermanfaat bagi pertumbuhan anak. Sosis ikan dapat dikombinasikan dengan sumber gizi lain untuk meningkatkan nilai gizinya, salah satunya adalah upaya peningkatan zat besi untuk mengatasi stunting dan anemia defisiensi besi.

Penelitian terhadap sosis ikan yang disubtitusi dengan rumput laut yang telah dilakukan sebelumnya bertujuan untuk mengetahui pengaruh terhadap sifat fisik dan organoleptik sosis. Rumput laut dapat memperbaiki sifat fisik sosis ikan karena mengandung senyawa yang dapat meningkatkan elastisitas sosis. (Rauf et al., 2015; Sulistyaningrum, 2019). Selain itu, rumput laut khususnya jenis Gracilaria sp. memiliki kandungan zat besi yang tinggi. Gracilaria changgi memiliki kandungan zat besi sebesar 95,6 mg per 100 g (Norziah et al., 2000), sehingga perlu dilakukan penelitian tentang penambahan rumput laut Gracilaria sp. dalam sosis. Penelitian ini 
bertujuan untuk mengetahui pengaruh penambahan Gracilaria sp. terhadap mutu produk sosis ikan bandeng, meliputi kadar proksimat dan zat besi, kekuatan gel strength dan kekerasan sosis, serta tingkat penerimaan panelis.

\section{BAHAN DAN METODE}

Waktu dan Lokasi

Penelitian ini dilakukan selama bulan Oktober hingga Desember 2019 bertempat di Unit Teaching Factory Pengolahan Politeknik Kelautan dan Perikanan Karawang.

\section{Persiapan Alat dan Bahan}

Bahan utama yang digunakan dalam penelitian ini adalah ikan bandeng dan rumput laut Gracilaria sp. (yang diperoleh dari Koperasi Agar Makmur Desa Tambaksari, Kecamatan Tirtajaya, Kabupaten Karawang). Sedangkan pada bahan yang digunakan pada pembuatan sosis antara lain tepung tapioka, putih telur, lada bubuk serta bumbu rempahrempah. Alat yang digunakan antara lain meat separator, food processor, sausagestuffer, lemari asap dan panci perebusan.

Ikan bandeng diambil dagingnya untuk dilumatkan sebagai bahan baku utama sosis ikan. Rumput laut direndam menggunakan media larutan tepung beras $5 \%$ selama 9 jam dan dengan larutan $\mathrm{CaO}$ $0,5 \%$ selama 10 menit. Rumput laut dicuci dan dibersihkan dari kotoran, potongan kulit kerang atau siput. Rumput laut kemudian dikeringkan hingga berubah warna menjadi kecokelatan, untuk selanjutnya diproses menjadi bubur. Rumput laut dihaluskan menggunakan air hangat (suhu $60-70^{\circ} \mathrm{C}$ ) hingga terbentuk bubur, kemudian dipanaskan hingga matang (Princestasari \& Amalia, 2015).

\section{Pembuatan Sosis Ikan Bandeng}

Pembuatan sosis ikan bandeng berdasarkan SNI 7755: 2013 dengan modifikasi ikan bandeng segar dibersihkan kemudian diambil dagingnya (fillet). Fillet daging bandeng dilumatkan kemudian dilakukan proses pencucian (leaching) sebanyak 1 (satu) kali dan ditiriskan hingga diperoleh lumatan daging ikan bandeng yang kering, bersih dan halus.

Lumatan daging ikan bandeng dicampur dengan bubur Gracilaria sp. sesuai perbandingan 1 : 8. Campuran adonan tersebut diberi garam, kemudian digiling hingga membentuk tekstur yang elastis. Selanjutnya adonan diberi bumbu dan rempah kering kemudian dimasukkan ke selongsong sosis. Sosis direbus dalam dua tahap yaitu perebusan dengan suhu $45-50^{\circ} \mathrm{C}$ selama 20 menit kemudian dilanjutkan perebusan dengan suhu 80$90^{\circ} \mathrm{C}$ selama 30 menit. Sosis yang telah direbus kemudian ditiriskan dan didinginkan (Kharisma et al., 2016).

\section{Pengujian Kualitas Sosis Ikan Bandeng}

Pengujian kualitas sosis ikan meliputi pengujian terhadap sifat fisikokimia dan sensori. Pengujian sifat fisikokimia meliputi uji proksimat berdasarkan AOAC (1990), yaitu pengukuran kekuatan gel serta pengukuran kekerasan sosis. Evaluasi sensori dilakukan dengan menggunakan uji ranking hedonik. Parameter yang digunakan pada uji hedonik antara lain tingkat kesukaan warna, rasa, aroma dan keseluruhan (overall).

\section{Pengolahan Data}

Pengolahan data menggunakan aplikasi SPSS versi 23.0. dengan metode parametrik yaitu uji t berpasangan untuk pengujian proksimat, gel strength dan kekerasan, serta metode non parametrik dengan uji Friedmann untuk uji hedonik. Uji $t$ berpasangan digunakan untuk menguji 2 (dua) kelompok yang saling berhubungan seperti hubungan proses sebelum dan sesudah seperti pada penelitian Anggraeni (2014). Uji t berpasangan juga dapat digunakan untuk membandingkan sampel percobaan 
dengan sampel komersial seperti pada penelitian Nantami (2011).

\section{HASIL DAN BAHASAN \\ HASIL}

Uji Proksimat

Kadar air pada sosis ikan bandeng yang telah dilakukan penambahan bubur rumput laut Gracilaria sp. (A1) adalah $71,26 \%$, lebih besar dari formulasi tanpa penambahan bubur rumput laut Gracilaria sp. (A0) yang sebesar 70,05\%. Kadar abu pada produk A1 sebesar 2,06 $\%$, lebih tinggi jika dibandingkan dengan produk A0 yang sebesar $1,97 \%$. Kadar lemak pada produk A1 adalah sebesar $2,58 \%$, lebih rendah dibandingkan dengan produk A0 yang sebesar 3,12\%. Hasil pengujian protein pada produk A1 sebesar 11,49\%, lebih rendah dibandingkan dengan produk A0 yang sebesar 13,12\%. Sedangkan hasil pengujian serat kasar pada produk A1 sebesar 2,89\%, lebih tinggi jika dibandingkan dengan produk A0 yang sebesar 2,35\%. Sementara itu hasil pengujian Fe produk A1 sebesar 0,758 $\mathrm{mg} / 100 \mathrm{~g}$, lebih tinggi dibandingkan dengan produk A0 yang sebesar 0,692 $\mathrm{mg} / 100$ g. Hasil pengujian proksimat dapat dilihat pada Tabel 1.

Tabel 1. Hasil Pengujian Proksimat Sosis Ikan Bandeng

Table 1. Proximate Test Results of Milkfish Sausage

\begin{tabular}{llll}
\hline \multicolumn{1}{c}{ Parameter } & \multicolumn{3}{c}{ Kadar } \\
\cline { 2 - 4 } & \multicolumn{1}{c}{ A0 } & \multicolumn{1}{c}{ A1 } & \multicolumn{1}{c}{ Syarat SNI } \\
\hline Air $(\%)$ & $70,05 \pm 0,54$ & $71,26 \pm 0,30$ & maks 68 \\
Abu $(\%)$ & $1,97 \pm 0,28$ & $2,06 \pm 0,18$ & maks 2,5 \\
Lemak $(\%)$ & $3,12 \pm 0,01$ & $2,58 \pm 0,36$ & maks 7 \\
Protein $(\%)$ & $13,12 \pm 0,48$ & $11,49 \pm 0,49$ & Min 9 \\
Serat kasar $(\%)$ & 2,35 & 2,89 & - \\
Fe (mg/100 g) & 0,692 & 0,758 & - \\
\hline
\end{tabular}

Keterangan:

A0: Sosis ikan bandeng tanpa penambahan bubur Gracilaria sp.

A1: Sosis ikan bandeng dengan penambahan bubur Gracilaria sp.

\section{Uji Gel Strength dan Kekerasan}

Pada pengukuran gel strength diperoleh nilai yang lebih tinggi pada sosis ikan bandeng yang telah dilakukan penambahan bubur rumput laut Gracilaria sp. (A1) yaitu $4.305 \mathrm{~g} / \mathrm{cm}^{2}$ dari pada sosis ikan bandeng yang tidak dilakukan penambahan bubur rumput laut Gracilaria sp. (A0) yaitu $2.986,3 \mathrm{~g} / \mathrm{cm}^{2}$. Hasil uji kekerasan produk A1 juga lebih tinggi sebesar 3.845,9 gf jika dibandingkan dengan produk A0 sebesar $2.573,2$ gf. Hasil pengujian gel strength dan kekerasan dapat dilihat pada Tabel 2.

Tabel 2. Hasil Pengujian Gel Strength dan Kekerasan Table 2. Gel Strength and Hardness Test Results

\begin{tabular}{lll}
\hline \multicolumn{1}{c}{ Parameter } & \multicolumn{1}{c}{ A0 } & \multicolumn{1}{c}{ A1 } \\
\hline Kekerasan $(\mathrm{gf})$ & $2573,2 \pm 533,9$ & $3845,9 \pm 250,3$ \\
Gel strength $\left(\mathrm{g} / \mathrm{cm}^{2}\right)$ & $2986,3 \pm 1227,9$ & $4305,1 \pm 1758,6$ \\
\hline
\end{tabular}

Keterangan:

A0: Sosis ikan bandeng tanpa penambahan bubur Gracilaria sp.

A1: Sosis ikan bandeng dengan penambahan bubur Gracilaria sp. 


\section{Uji Hedonik}

Pengujian hedonik menggunakan parameter uji warna, aroma, tekstur dan rasa terhadap produk A0 dan A1. Adapun hasil pengujiannya dapat dilihat pada Tabel 3.

Tabel 3. Hasil Pengujian Hedonik Sosis Ikan Bandeng

Table 3. Hedonic Test Results of Milkfish Sausage

\begin{tabular}{lcc}
\hline \multirow{2}{*}{ Parameter } & \multicolumn{2}{c}{ Skor Hedonik } \\
\cline { 2 - 3 } & A0 & A1 \\
\hline Warna & $3,25 \pm 0,44$ & $3,93 \pm 0,85$ \\
Aroma & $3,06 \pm 0,25$ & $3,18 \pm 0,54$ \\
Tekstur & $3,00 \pm 0,36$ & $3,06 \pm 0,44$ \\
Rasa & $2,80 \pm 0,77$ & $2,80+0,77$ \\
\hline
\end{tabular}

Keterangan:

A0: Sosis ikan bandeng tanpa penambahan bubur Gracilaria sp.

A1: Sosis ikan bandeng dengan penambahan bubur Gracilaria sp.

\section{BAHASAN}

Pada penelitian ini digunakan lumatan daging bandeng yang telah dilakukan pencucian sebanyak 1 (satu) kali menggunakan air es dengan volume dua kali lipat berat fillet bandeng untuk menghindari berkurangnya kandungan gizi didalam daging ikan bandeng. Selain menekan kehilangan mineral dengan mengurangi frekuensi leaching, kandungan mineral tertentu dapat ditingkatkan dengan penambahan sumber mineral lain dari luar, contohnya adalah penambahan bubur Gracilaria sp. untuk meningkatkan kadar mineral.

Sosis dicetak menggunakan selongsong/casing sehingga membentuk penampakan silindris yang kompak. Casing sosis yang digunakan untuk wadah adonan sosis dalam penelitian ini terbuat dari polietilen yang bersifat food grade. Pada umumnya sosis ikan terbuat dari daging ikan yang telah mengalami proses surimi. Hal ini dimaksudkan untuk menghilangkan protein sarkoplasma yang menghalangi pembentukan gel, sehingga tersisa protein myofibril yang mampu membentuk gel dengan baik (Kharisma et al., 2016). Namun, semakin banyak daging ikan yang mengalami proses pencucian (leaching), dapat mengalami penurunan mutu rasa dan penurunan gizi yang mudah larut dalam air seperti vitamin dan mineral.

Pencucian (leaching) dilakukan sebanyak dua kali dengan tujuan menghilangkan darah yang tersisa pada daging, membantu membentuk jaringan gel (gelling agent), serta meningkatkan kualitas kecerahan warna sosis. Pada proses leaching perlu ditambahkan garam sebesar $0,3 \%$ untuk membantu pembentukan gel (Abdulrahman, 1987).

Pada produk fish jelly, proses pencampuran merupakan kunci penting untuk menghasilkan tekstur produk yang kenyal. Lumatan daging ditambah dengan garam kemudian dicampur dalam food processor untuk mendapatkan tekstur lumatan yang lengket, kemudian dicampur dengan bumbu dan kondimen lain. Konsentrasi garam yang digunakan sebesar 3\% dari berat adonan. Kombinasi kandungan garam dan es batu (suhu dingin) dapat membantu meningkatkan pembentukan tekstur elastis pada adonan.

Komposisi kimia sosis ikan bandeng yang diperkaya bubur Gracilaria sp. mengalami peningkatan nilai kadar air dan kadar abu, namun mengalami penurunan kadar lemak dan protein. Sementara itu ikan bandeng memiliki kadar zat besi yang cukup tinggi, sesuai dengan pernyataan 
Hafiludin (2015) dimana ikan bandeng yang diperoleh dari perairan tawar memiliki kandungan $\mathrm{Fe}$ sebesar 0,327 mg/100 gram, 10 (sepuluh) kali lipat lebih besar dibandingkan ikan bandeng yang diperoleh dari perairan payau, yaitu 0,032 $\mathrm{mg} / 100$ gram.

Kadar air sangat mempengaruhi tekstur, sehingga produk sosis menjadi lunak/kurang elastis. Sementara itu sosis dengan penambahan rumput laut memiliki kadar air yang lebih tinggi dikarenakan kandungan agar dalam rumput laut mampu mengikat air dan mempertahankannya di dalam matriks gel (Rosyidi et al., 2008). Kadar abu dapat dipengaruhi oleh pemakaian selongsong yang dapat menyebabkan ikatan air yang semakin stabil. Kehilangan air selama pemasakan yang semakin kecil dapat menyebabkan persentase kadar abu semakin besar (Poernomo et al., 2011).

Kadar lemak pada dua kelompok percobaan masih memenuhi syarat SNI maksimal 7\%, dimana lemak pada ikan dihilangkan pada proses leaching karena turut mempengaruhi gel forming ability. Kadar lemak pada sosis rumput laut lebih rendah karena rumput laut mengandung lemak yang cukup rendah, sekitar 3-11\% (Princestasari \& Amalia, 2015). Kadar protein pada sosis ikan bandeng tanpa penambahan rumput laut (A0) lebih tinggi dibandingkan sosis dengan penambahan rumput laut (A1). Hal ini disebabkan oleh kadar protein rumput laut Gracilaria sp. cukup rendah, sekitar 0,31\% (Chaidir, 2007), sehingga mengurangi kadar protein secara signifikan $(\mathrm{P} 0,000<0,005)$. Sedangkan penambahan rumput laut pada sosis ikan bandeng dapat meningkatkan nilai serat.

Proses leaching bertujuan untuk menghasilkan mutu gel yang baik dan kuat. Proses leaching dibatasi 1 kali untuk mengurangi hilangnya mineral Fe selama proses pengolahan, namun disisi lain menyebabkan gel forming ability pada lumatan daging ikan bandeng berkurang. Penambahan rumput laut Gracilaria sp. diduga dapat meningkatkan nilai tekstur dan kekuatan gel, dimana kemampuan Water Holding Capacity (WHC) meningkat sehingga kadar air turut meningkat. Hal ini sejalan dengan penelitian Rosyidi, et al. (2008) bahwa penambahan rumput laut pada chicken nugget dapat meningkatkan nilai WHC pada produk.

Pada parameter warna, aroma dan tekstur, kelompok sosis ikan bandeng yang telah ditambahkan bubur rumput laut Gracilaria sp. (A1) memiliki nilai uji hedonik lebih tinggi dibandingkan dengan sosis ikan bandeng tanpa penambahan bubur rumput laut Gracilaria sp. (A0). Hal ini menunjukkan penambahan bubur Gracilaria sp. dapat meningkatkan keberterimaan produk sosis ikan bandeng meskipun peningkatan ini tidak signifikan. Rata-rata panelis menyukai tekstur sosis yang lebih kenyal dan warna yang lebih menarik. Pada parameter rasa, kedua kelompok memiliki nilai yang sama. Hal ini dapat berarti bahwa penambahan bubur Gracilaria sp. tidak mempengaruhi rasa pada sosis ikan.

\section{SIMPULAN}

Penambahan bubur Gracilaria sp. sebanyak $1: 8$ (70 g : $580 \mathrm{~g})$ dari berat lumatan daging ikan dapat menghasilkan produk sosis ikan yang disukai oleh panelis pada atribut warna, tekstur serta aroma. Penambahan bubur Gracilaria sp. meningkatkan nilai tekstur dan gel forming ability, serta meningkatkan kadar serat kasar dan zat besi pada sosis ikan, namun mempengaruhi penurunan kadar protein dan lemak. Produk sosis ikan bandeng dapat dikonsumsi untuk meningkatkan asupan zat besi dan serat bagi konsumen.

\section{UCAPAN TERIMA KASIH}

Penulis mengucapkan terima kasih kepada Politeknik Kelautan dan 
Perikanan Karawang yang telah memberikan dana penelitian terapan bagi dosen pada tahun anggaran 2019. Penulis juga berterima kasih kepada Kepala Laboratorium Pengujian BLUPPB Karawang serta Ibu Natalia Prodiana, M.Sc dari BBP2HP Jakarta yang telah membantu penulis dalam melakukan analisis kandungan sampel.

\section{DAFTAR PUSTAKA}

Abdulrahman. (1987). Teknologi Pengolahan Surimi. Jakarta: Balai Bimbingan dan Pengujian Mutu Hasil Perikanan.

Anggraeni, D. (2014). Rasio Tepung Porang (Amorphophallus Muelleri Blume) sebagai Bahan Pengikat: Tepung Maizena sebagai Bahan Pengisi Terhadap Karakteristik Sosis Ayam [Doctoral dissertation] Malang: Universitas Brawijaya. http://repository.ub.ac.id/149545/

[AOAC] The Association of Official Analytical Chemists. (1990). Official Methods of Analysis, 15 th Edition. USA: The Association of Analytical Chemists, Inc.

[BPS] Badan Pusat Statistik. (2015). Kabupaten Karawang dalam Angka. Karawang: Badan Pusat Statistik Kabupaten Karawang. https://karawangkab.bps.go.id/stati ctable/2016/11/04/112/produksiperikanan-budidaya-dirincimenurut-jenis-ikan-dan-budidayadi-karawang-2015.html

[BSN] Badan Standardisasi Nasional. (2013). SNI 7755: 2013 Sosis Ikan. Jakarta: Badan Standardisasi Nasional.

Burry, S., Tato, I., Nunes, M., Morais, R. (2011). Functional VegetableBased Sausages for Consumption by Children. Food and Nutrition Sciences, 2011(2), 494-501. https://repositorio.ucp.pt/handle/10 400.14/7570
Chaidir, A. (2007). Kajian Rumput Laut sebagai Sumber Serat Alternatif untuk Minuman Berserat [tesis]. Bogor: Sekolah Pascasarjana, Institut Pertanian Bogor.

Direktorat Gizi Masyarakat. (2016). Buku Pedoman Pencegahan Anemia Rematri dan WUS. Jakarta: Direktorat Jenderal Kesehatan Masyarakat Kementrian Kesehatan Republik Indonesia. https://cegahstunting.id/wpcontent/uploads/2018/01/BukuPedoman-Pencegahan-AnemiaRematri-dan-WUS.pdf

Hafiludin, H. (2015). Analisis Kandungan Gizi pada Ikan Bandeng yang Berasal dari Habitat yang Berbeda. Jurnal Kelautan: Indonesian Journal of Marine Science and Technology, 8(1), 37$43 . \quad \mathrm{https}: / / \mathrm{eco}-$ entrepreneur.trunojoyo.ac.id/jurnal kelautan/article/view/811

Kharisma, M., Dewi, E. N., \& Wijayanti, I. (2016). Pengaruh Penambahan Isolat Protein Kedelai yang Berbeda dan Karagenan Terhadap Karakteristik Sosis Ikan Patin (Pangasius pangasius). Jurnal Pengolahan dan Bioteknologi Hasil Perikanan, 5(1), 44-48. https://ejournal3.undip.ac.id/index. php/jpbhp/article/view/10817

Norziah, M. H., \& Ching, C. Y. (2000). Nutritional Composition of Edible Seaweed Gracilaria changgi. Food chemistry, 68(1), 69-76. https://www.sciencedirect.com/sci ence/article/abs/pii/S03088146990 01612

Princestasari, L. D., \& Amalia, L. (2015). Formulasi Rumput Laut Gracilaria Sp. dalam Pembuatan Bakso Daging Sapi Tinggi Serat dan Iodium. Jurnal Gizi dan Pangan, 10(3), 185-196. https://journal.ipb.ac.id/index.php/j gizipangan/article/view/11582 
Poernomo, D., Suptijah, P., \& Nantami, N. (2011). Karakteristik Sosis Rasa Ayam Dari Surimi Ikan Lele Dumbo (Clarias gariepinus) Dengan Penambahan 106 Isolat Protein Kedelai. Jurnal Pengolahan Hasil Perikanan Indonesia, 14(2), 106114.

https://jurnal.ipb.ac.id/index.php/jp hpi/article/view/5319

Rauf, N. H., Sulistijowati, R. S., \& Harmain, R. M. (2015). Mutu Organoleptik Sosis Ikan Lele yang Disubtitusi dengan Rumput Laut. Jurnal Nike, 3(3), 125-129. http://ejurnal.ung.ac.id/index.php/n ike/article/view/1323

Rosyidi, D., Widati, A. S., \& Prakoso, J. (2008). Pengaruh penggunaan rumput laut terhadap kualitas fisik dan organoleptik chicken nuggets.
Jurnal Ilmu dan Teknologi Hasil Ternak, 3(1), 43-51. http://repository.ub.ac.id/136473/

Sulistyaningrum, T. W. (2015). Kajian penambahan karaginan dari rumput laut (Eucheuma cottoni) terhadap sifat-sifat organoleptik sosis ikan Lele (Clarias gariepinus). Jurnal Ilmu Hewani Tropika (Journal Of Tropical Animal Science, 4(2), 66-70. https://unkripjournal.com/index.ph $\mathrm{p} / \mathrm{JIHT} /$ article/view/73

Waluyo, W., Permadi, A., Fanni, N. A., \& Soedrijanto, A. (2019). Analisis Kualitas Rumput Laut Gracilaria verrucosa di Tambak Kabupaten Karawang, Jawa Barat. Grouper, 10(1), 32-41. http://grouper.unisla.ac.id/index.ph $\mathrm{p} /$ grouper/article/view/50 